\title{
Türkçede Sözcük ve Dil Bilgisi İlişkisi: Dil Bilgisel Eşdizim Kalıpları *
}

\section{Lexicogrammar in Turkish: Grammatical Collocation Patterns}

\author{
Nuh Doğan a,** \\ ${ }^{a}$ Doç. Dr., Johannes Gutenberg-Universität, Institut für Slavistik, Turkologie und zirkumbaltische Studien, Turkologie, Mainz/ Deutschland. \\ Ondokuzmayıs Üniversitesi, Fen-Edebiyat Fakültesi Türk Dili ve Edebiyatı Bölümü, Samsun/ Türkiye. \\ ORCID: 0000-0001-8935-8428
}

\section{MAKALE BİLGİİ}

\section{Makale Geçmişi:}

Başvuru tarihi: 05 Kasım 2020

Düzeltme tarihi: 10 Kasım 2020

Kabul tarihi: 12 Kasım 2020

\section{Anahtar Kelimeler:}

Eşdizimlilik

Dil bilgisel eşdizimlilik

Dil bilgisi kalıpları

Dilbilgiselleşme

Sözcük-dilbilgisi ilişkisi

\section{ARTICLE INFO}

\section{Article history:}

Received 05 November 2020

Received in revised form 10 November 2020

Accepted 12 November 2020

\section{Keywords:}

Collocation

Grammatical collocations

Grammar patterns

Grammaticalization

Lexico-grammar
ÖZ

Sözcük ve dil bilgisi arasında sıkı bir ilişki vardır. Dil bilgisinin tümünü ya da bir kısmını sözcükler belirler. Dil bilgisi sözcüklerin diğer sözlüksel unsurla sıklıkla kullanıldıkları sentagmatik çevrede oluşur. Ne kadar sözcük varsa o kadar da dil bilgisinin olduğu söylenebilir. Dil bilgisinin tümüyle belirlenmesi sözcügün tüm dil bilgisel davranışlarının belirlenmesiyle ancak mümkündür. Buna karşın sözcüklerin kullanıldıkları belirgin dil bilgisi örüntüleri ve yaygın dil bilgisi kalıpları vardır ve bunlar derlem aracılığıyla kolaylıkla belirlenebilir. Dil bilgisel kalıplar sözcügün belirli dil bilgisel kategorilerle ve dil bilgisel unsurlarla sıklıkla aynı dizimde birlikte kullanılmasıyla oluşur. Bu çalışmada, sözlüksel unsurların, özellikle fiillerin hangi belirli ve yaygın dil bilgisel eşdizim kalıpları meydana getirdiği, aynı dizimde sıklıkla ve öncelikle birlikte kullanıldığ 1 dil bilgisel kategori ve biçimbirimlerin neler olduğu ve hangi anlamsal ve işlevsel ayrımları ortaya çıkardığı belirlenmiştir.

\section{Giriş}

Sözcüklerin dil bilgisel açıdan iyi biçimlenmesi ve anlamsal bağdaşıklığının olması onların aynı dizimde birlikte kullanılabilmesi için yeterli değildir. Dil bilgisi ve anlam müsaade etse bile sözcüklerin her sözcük birimiyle (lexem) ve her sözcük biçimiyle (word-form) ya da her dil bilgisel

\section{A B S T R A C T}

There is a close relationship between vocabulary and grammar. Words determine all or part of the grammar. Grammar occurs in a syntagmatic environment where words are often used with other lexical elements. It can be said that the more words there are, the more grammar. The complete determination of grammar is only possible by determining all grammatical behaviors of the word. On the other hand, there are clear grammatical patterns and common grammar patterns in which words are used, and these can be easily identified through corpus. Grammatical patterns are formed when the word is used together with certain grammatical categories and grammatical elements, often in the same syntagm. In this study, it was determined which specific and common grammatical collocation patterns formed by lexical elements, especially verbs, what grammatical categories and morphologies are frequently and primarily used together in the same syntagm, and which semantic and functional distinctions they reveal.

*Bu makale kuramsal açıdan X. Uluslararası Dünya Dili Türkçe Sempozyumu'nda (17-19 Ekim 2018, Eskişehir) sunulan “Türkçede Dil Bilgisel Eşdizimlilik” başlıklı kısa bildiriye dayanmaktadır. Kimi örnek ve ifadeler tekrar etmekle birlikte hem içeriği hem biçimsel yapısı hem de kuramsal çerçevesi tümüyle değiştirilmiş, yeni bir yaklaşımla tekrar kaleme alınarak hacimli bir makaleye dönüştürülmüştür.

** Sorumlu yazar/Corresponding author.

e-posta: nuhdogan55@hotmail.com 
birbirini kısıtlama ve karşılıklı gerektirimin, sonunda da bazı sözlüksel ve dil bilgisel normların oluşmasına neden olur. Sözcüklerin birbirini gerektirmesi ve kısıtlaması dil biliminde genel olarak eşdizim (collocation and colligation) terimiyle anılan, sözcüğ̈̈n gramerinin (lexico-grammar), bir başka deyişle sözlüksel (lexical pattern) ve dil bilgisel kalıplarının (grammatical pattern) oluşmasını sağlar. Sözcügün sözlüksel kalıpları sözlüksel eşdizimlilikle (collocation), dil bilgisel kalıpları ise dil bilgisel eşdizimlilikle (colligation) ilgilidir. Bunun için eşdizimlilik son dönemlerde yazın alanında dil bilgisel eşdizimlilik ve sözlüksel eşdizimlilik olmak üzere iki temel başlıkta incelenir. Bu terim ve kavramların her ikisi de sözlüksel unsurların diğer sözlük unsurlarıyla ve belirli dil bilgisel unsur, yap1 ya da kategorilerle sıklıkla birlikte kullanılması sonucunda meydana gelen kalıplaşma (formulaic) olgusunu ifade eder. Kalıplaşmanın sözlüksel ve dil bilgisel olmak üzere iki biçimi vardır. Kalıplaşma, sıklığın etkisiyle dillerin kaçınılmaz şekilde maruz kaldığ tümünün ya da kimi dil bilgisel yapıların oluşmasını sağlayan, yeni söz varlığı ögelerini ortaya çıkaran, eşdizim kalıplarıyla anlam arasındaki sıkı ilişkiden dolayı sözcüğe ve dil bilgisel unsurlara yeni anlam ve işlevler kazandıran doğal bir süreçtir.

Sözcük ve dil bilgisi birbirinden ayrı düşülemez. Ne kadar sözcük varsa o kadar da (sözcük) dil bilgisinin olduğu söylenebilir ${ }^{1}$. Bu bakımdan tüm sözcüklerin birliktelik kullanımları incelenmeden dil bilgisinin tümüyle belirlenmesi mümkün değildir. Buna karşın sözcüklerin kullanıldıkları belirgin dil bilgisi örüntüleri ve yaygın dil bilgisel eşdizim kalıpları belirlenebilir. $\mathrm{Bu}$ çalışmada, sözcük grameri (lexico-grammar, lexical grammar) yaklaşımlarından hareketle Türkçede sözcük ile dil bilgisi arasında ilişkinin genel mahiyeti ana hatlarıyla belirlenmeye çalışılmıştır. Türkçede sözlüksel unsurların özellikle fiillerin isimlerle ve diğer söz dizimsel kategorilerle aynı dizimde birlikte kullanımından ortaya çıkan yaygın ve belirgin dil bilgisel kalıpların neler olduğu derlem tabanlı bir yöntemle tespit edilmiştir. Bu amaca yönelik Türkçenin kelime sıklığı listesinden (bk. Aksan vd. 2012) rastlantısal olarak seçilen, farklı sözcük türlerini temsil edebilecek, kullanım sıklığı yüksek sözcüklerin birliktelik kullanımı Türkçe Ulusal Derlemden (TUD) sorgulanmıştır. Sözlüksel unsurların, özellikle de fiillerin hangi belirli ve yaygın dil bilgisel eşdizim kalıpları meydana getirdiği ya da aynı dizimde sıklıkla ve öncelikle birlikte kullanıldığ neler olduğu ve hangi anlamsal ve işlevsel ayrımları ortaya çıkardığı belirlenmiştir. Çalışkan (2019)'da özellikle -mA ve -dIk ile teşkil edilen tümleç yan cümlelerinin hangi fiillerle birlikte ne sıklıkla kullanıldığı nispeten belirlenir. Ancak fiillerin söz konusu biçimbirimlerle eşdizim kullanımı tek bir aşama ve düzeyde ele alındığından dil bilgisel eşdizimiliğin gerçek ve bütüncül görünümü ve prototip dil bilgisi ve anlam kalıpları elde edilememiştir. Türkçede dil bilgisel eşdizim kalıpları çoğunlukla sözlüksel eşdizim kalıplarında ortaya çıkmasına karşın fiiller sözlüksel kalıplaşma olmadan da belirli dil bilgisel kategoriler ve biçimbirimlerle anlamsal ayrımlar oluşturacak şekilde kullanılabilir ve bundan yine belirli dil

$1 \mathrm{Bu}$ yaklaşımın uygulamalarından birinin Yüceol Özezen'in (2009) “De- Fiilinin Grameri” adlı çalışması olduğu söylenebilir. bilgisel kalıplar ortaya çıkabilir. $\mathrm{Bu}$ araştırmanın, eşdizimlilik bağlamında hem sözcükler arasında hem de sözcük ile dil bilgisi ara yüzünde oluşan kompleks ve prototip kalıpları ortaya çıkaran sistematik bir yaklaşım önerdiği söylenebilir. Bu yaklaşım, dil bilgisel eşdizimlerin sözlüksel eşdizimlerle ortaya çıkmasından kaynaklanan karmaşanın önüne geçebilir ve ileriye dönük hazırlanacak Türkçenin Eşdizim Sözlüğü'nün kuramsal altyapısında kullanılabilir. Çalışma sözcük ile dil bilgisi arasındaki ilişkinin belirlenmesi adına sınırlı sözcüklerden ve onların meydana getirdiği belirli dil bilgisel kalıplardan oluştuğundan bu hâliyle bir başlangıç ve öneri niteliğindedir. Kapsamlı derlem çıkışlı çalışmalar çok daha farklı sonuçların elde edilmesine imkân verebilir.

\section{Sözcük ve Dil Bilgisi İlişskisi}

Sözcük ve dil bilgisi ya da sözlük ve söz dizimi dil biliminde uzun süre birbirinden bağımsız olarak görülmüş iki alandır. Ancak durum pek zannedildiği gibi değildir. Geleneksel olarak birbirinden ayrı tutulan sözcük ve dil bilgisi alanının gerçekte ayrılmaz özelliklerinin ve ilişkisinin olduğu rahatlıkla söylenebilir. Derlem dil bilimi (corpus linguistics) ve özellikle eşdizimlilik araştırmaları sözcük ile dil bilgisi arasında çok yakın bir ilişki ve etkileşimin olduğunu göstermektedir. Sözcüklerin diğer sözcüklerle birliktelik kullanımından belirli sözlüksel ve dil bilgisel kalıplar oluşur. Her sözcüğün kendine özgü bir dil bilgisinin olduğu, sözcüğü dil bilgisinden dil bilgisini sözcükten ayrı düşünmenin mümkün olamayacağı ileri sürülebilir. Bunun sözcüğün gizil olarak taşıdığı dil bilgisel bilgiden kaynaklandığı söylenebilir. Zira eşdizimlilik ve deyim bilimi (phraseology) üzerine yapılan derlem çıkışlı dil bilimi çalışmaları dilin yüksek derece kalıplaşmış sözlüksel ve dil bilgisel yapılardan oluştuğunu ortaya koyar. Dil birimlerinin sıklıkla birlikte kullanılmalarından ortaya çıkan karşılıklı ya da birlikte seçme (co-selection) potansiyeli, donuk ya da yarı-donuk sözlüksel ve dil bilgisel yapıların oluşmasına yol açar. Bu, sözcük ve dil bilgisi arasındaki ilişki ve bağımlılıktan kaynaklanır. Sözcük dil bilgisel yapıları oluştururken dil bilgisinin de bir noktaya kadar sözcükleri ortaya çıkardığı söylenebilir. Özellikle sözcüklerin farklı anlamlar kazanmasında ve işlevsel görevler üstlenmesinde dil bilgisinin sözcükler üzerinde baskın bir etkisi vardır. (bk. Bölüm 4)

Sözcük ve dil bilgisi ilişkisi çeşitli yapısalcı dil bilimi kuramlarında farklı terimlerle anılmıştır. Hangi terim ve kavramla ele alınırsa alınsın söz konusu yapısalcı yaklaşımlarda sözlük ve dil bilgisi ya da söz diziminin birbirinden farklı olmadığı, ikisinin de birer biçim-anlam çifti olan dil bilimsel bir gösterge olduğu fikri yatar. Dil bilgisel bir yapının belirli bir anlam ya da işlevle doğrudan ilgili olan dil bilimsel bir ifade ya da gösterge olduğu, onun biçim ya da anlamının doğrudan ve birbirinden bağımsız türetilemeyeceği söylenebilir. Sözcüğün olduğu kadar dil bilgisel yapıların da anlamı vardır. Anlam yapıları meydana getirirken yapılar da anlamları meydana getirir. Bir sözcük bir yapıda ancak sözcüğün anlamı söz konusu yapının anlamıla semantik olarak örtüşürse kullanılabilir (Stefanowitsch \& Gries, 2004). Sözcük ya da anlam belirli yapılarla ilgili olabileceği gibi bir yapı da belirli bir sözcük ya da anlamla ilgili olabilir. Hülasa sözcük ile dil bilgisi birbirinden bağımsız değildir (bk. Römer, 2009). Dil bilgisinin tümünü ya da bir kısmını meydana getiren 
sözcüktür. Sözcük ya da sözcügün anlamı tekrar söz dizimi ya da dil bilgisel yapının anlamını, dil bilgisel yapının anlamı da sözcüğün anlamını etkiler, hatta bir aşamaya kadar sözcügün anlamını dil bilgisel yapılar belirler. Sözcüklerden hareketle dil bilgisel yapıları, dil bilgisel yapılardan hareketle de sözcüğün anlamının ya da anlamalarının belirlenebileceği söylenebilir. $\mathrm{Bu}$ yaklaşım bir taraftan aynı ya da yakın anlam üreten dil bilgisel yapıları diğer taraftan da benzer ya da aynı dil bilgisel yapıları üreten sözlüksel birimleri ortaya çıkaracaktır.

Dil bilgisel eşdizimliliğin sözcük ve dil bilgisi etkileşiminin ve ilişkisinin bir ürünü olarak oluştuğu söylenebilir. Sözlük ve dil bilgisinin birbirinden ayrı düşünülemeyeceği dikkate alındığında dil bilgisel eşdizimliliğin dilin sözlük-gramer düzeyini (lexicogrammatical level) ifade ettiği ileri sürülebilir. Sözcüğün kendi dil bilgisel çevresini belirlemesi ve bu dil bilgisel yapıda sıklıkla kullanılması çeşitli işlev ve anlam ayrımları meydana getiren kalıplaşmaların dolayısıyla dil bilgisel eşdizimlerin ortaya çıkmasını sağlar. Dil bilgisel eşdimliliğin oluşumunda sözlüksel eşdizimliliğin önemli bir rolü vardır. Dil bilgisel eşdizimlilik çoğunlukla sözlüksel eşdizimlilik bağlamında ortaya çıkar. Buna karşın sözlüksel eşdizimlilik dil bilgisel eşdizimlilik için bir önkoşul değildir.

\section{Sözlüksel ve Dil Bilgisel Eşdizimlilik}

Eşdizimlilik, iki ya da daha fazla sözcüğün sıklık kullanımına bağlı olarak dil bilgisel ve anlamsal sınırlılık olmamasına karşın keyfi kullanım normlarının oluştuğu, unsurlarının birbirini kısıtladığı ve birbirini gerektirdiği, dilde sürekli tekrar eden sözcük birleşmeleri olarak tanımlanabilir. Bununla birlikte keyfi kullanım, kısıtlı değiştirim ve karşılıklı gerektirim sadece sözlük unsurları arasında gerçekleşmez. Siklık, sözlüksel unsurlarla dil bilgisel unsurlar arasında da birbirini gerektiren ve kısıtlı değiştirim imkânı veren keyfi kulanım normlarını ortaya çıkarabilir. Bundan ötürü yazın alanında eşdizimliliğin sözlüksel (lexical collocation) ve dil bilgisel (grammatical collocation) olmak üzere iki türünün olduğu kabul edilir ${ }^{2}$ (bk. Benson vd, 1997).

Sözlüksel eşdizimlilik, sıklıkla birlikte kullanılan, bundan ötürü unsurlarının birbirini gerektirdiği ve diğer sözcüklerle aynı dizimde kullanımının kısıtlandığı, ancak sınırlı değiştirim imkânlarının olduğu, buna karşın hangi sözcüklerle birlikte kullanılabileceği eş anlamlı çiftleri olsa bile tahmin edilemediği, anlam ve dil bilgisi müsaade etmesine rağmen diğer sözcüklerin dişlandığı, bu nedenle keyfi kullanım normlarının oluştuğu bir sözcük birleşmesi türü olarak kabul edilebilir. karışmak fiili, söz ve laf sözlük birimleriyle eşdizimlenirken, fiilin *konu, *konuşma ve

\footnotetext{
${ }^{2}$ Sözlüksel eşdizimlilik kullanılan yönteme göre yazın alanında sıklık temelli ve anlam temelli olmak üzere iki farklı kuramsal yaklaşımla ele alınır. Siklık temelli yaklaşımda derleme ve ondan elde edilen s1klik verilere dayanan ve istatistiksel olarak belirlenen iki ya da daha fazla sözcüğün alışagelmiş birliktelik kullanımlarını ifade eder. Bu yaklaşımda dilin doğal sözlüksel ve dil bilgisel kalıplarının dil birimlerinin sıklık kullanımının sayısal olarak belirlenmesi suretiyle tespit edilmesi amaçlanır. Anlam temelli yaklaşımda ise sözlükselleşme derecesine ve bileşenlerinin değiştirim sınırlılıklarına göre belirlenen bir sözcük birleşmesi (word combination) olarak ele alınır (Daha fazla bilgi için bk. Doğan, 2016).
}

*sohbet sözcükleriyle; söz ve laf sözcüklerinin de yakın anlamlı olmasına karşın *bulaşmak, *katışmak fiilleriyle eşdizimlenmesi dil bilgisi ve anlam müsaade etmesine rağmen keyfi olarak kısıtlanır. Yine laf sözcüğünün girmek fiil ile kullanımı varken $s \ddot{z} z$ ile birlikteliği dışlanır. söz ve laf isimleri karışmak fiilini gerektirirken karışmak da söz ve laf isimlerini gerektirir. $\mathrm{Bu}$, karışmak fiilinin eşdizime özgü özelleşmiş bir anlam kazanmasını ve sözcük birleşmesinin sözlükselleşmesini sağlamıştır:

\begin{tabular}{ll}
\multicolumn{2}{l}{ Tablo 1: Eşdizimlerin Bileşenleri } \\
\hline Taban (base) & Eşdizimleyen (Collocator) \\
\hline söze/ lafa & + karışmak \\
\hline söze/ lafa & + *bulaşmak \\
\hline lafa/ *söze & + girmek \\
\hline *konuya, *konuşmaya, & + karışmak \\
*sohbete & \\
\hline
\end{tabular}

Dil bilgisel eşdizimlilik “colligation” terimi ilk önce Firth (1968) tarafından kullanılmıştır. Dil bilgisel eşdizimlilik sadece eşdizimlilik araştırmalarında değil daha sonra ortaya çıkan farklı yapı merkezli dil bilimi kuramlarında, örneğin Hunston and Francis (2000)'de kalıp (pattern), Lewis (1997)'de sözlüksel öbek (lexical chunks), Goldberg (1995)'te yapı (construction) kavramı içinde de yer almış ve araştırılmıştır. Firth (1968) dil bilgisel eşdizimliliği "colligation “ söz dizimsel yapıda iki dil bilgisel kategorinin karşılıklı ilişkisi olarak tanımlar. Firth, "Ben onu izledim" örneğini vererek dil bilgisel eşdizimliliğin "colligation" [ben + onu + izledim] sözcük ve sözcük biçimlerinin birliktelik kullanımı arasında olmadığını; yalın durumda ve özne işlevindeki birinci tekil kişi zamiri ile geçişli fiilin geçmiş zaman biçimi ve nesne işlevinde yükleme durum kategorileri arasında gerçekleşen bir ilişki olduğunu ifade eder. Ancak sonraki çalışmalarda dil bilgisel eşdizimlilik "colligation “ teriminin içeriği farklı ilişkileri kapsayacak şekilde genişletilmiştir, kimi zaman da Firth'ten büsbütün farklı bir anlamda türlü sözlüksel ve dil bilgisel ilişkileri betimlemek için kullanılmıştır. Benson vd. (1997) de dil bilgisel eşdizimliliği "grammatical collocation" bir dil bilgisel unsurla bir sözlüksel unsur arasındaki ilişki ve kalıplaşma olgusu olarak ele alır. Benson vd (1997) dil bilgisel eşdizimliliği isim, fiil ve sıfat türünde özerk bir sözcükle bir edat, fiilimsi ya da yan cümle gibi dil bilgisi yapılarından oluşan öbek olarak tanımlar. Stubbs (2001) ise eşdizimliliği hem dil bilgisel kategori çiftleri hem de bir sözcük ve bir dil bilgisi çifti arasındaki ilişki olarak tanımlar. Dil bilgisel eşdizimlilik kimi zaman da sözlüksel eşdizimliliğin bir parçası ve türü kabul edilmiştir (Siepmann, 2005). Bugün artık dil bilgisel eşdizimlilik "colligation” çoğunlukla sadece sözlüksel kategori ile dil bilgisel kategori arasındaki kuvvetli çekim ya da gerektirim ilişkisini değil aynı zamanda bir sözcük ile dil bilgisel bir yapı arasındaki ilişkiyi ve bir sözcük ile dil bilgisel sözcük adı da verilen bir sözcük biçimi arasında meydana gelen çekim ve gerektirim ilişkilerini de karşılayacak şekilde kullanıldığı görülür (bk. Sinclair, 1998; Stubbs, 2001; Benson 1997).

Hoey (2005: 43) dil bilgisel eşdizimlilik "colligation" terimini daha geniş bir kavram olarak ele alır ve belirli özellikleri açısından betimler. Hoey (2005) dil bilgisel eşdizimliliğin özelliklerini belirlediği yaklaşımında dil bilimsel unsurlar arasında üç farklı birbirini gerektirme ve 
çekme ilişkisinin olduğunu dile getirir. Hoey'in üç kategoride (i, ii, iii) ele alıp öne sürdüğü dil bilgisel eşdizim biçimleri eleştirilebilir yanları olmakla birlikte Türkçe açısından ana hatlarıyla aşağıdaki gibi somutlaştırılabilir.

\section{i) Bir sözcüğün kendi öbek sınırları içinde ya da daha üst konumda tuttuğu ya da bundan kaçındığı dil bilgisel bir birliktelik}

Birinci (i) kategori Türkçede bir sözlüksel unsurla bir dil bilgisel kategori arasındaki ilişki olarak gerçekleşir. (1a)'da istemek fiili isim-fiil yan cümlesiyle, özellikle belirli bir sözcük biçimiyle kullanılır ancak (1b)'de istemek fiili diğer isim-fiil biçimbirimleriyle teşkil edilen yan cümle şekillerinden kaçınır, aksi durumda dil bilgisel olmayan cümleler ortaya çıkar:

1) Öğrenciler sinemaya git-mek istiyor

2) *Öğrenciler sinemaya * git-me/ *gidiş istiyor.

ii) Bir sözcüğün bir dizimdeki yeri tercih etmesi ya da bundan kaçınması

İkinci (ii) kategorinin daha çok durum (hâl) sisteminin katı söz dizimiyle sağlandığı diller için uygun bir belirleme olduğu söylenebilir. Bununla birlikte Türkçede ikinci (ii) kategorinin bir sözcük ile onun bir söz öbeğinde ya da cümlede kullanılabileceği pozisyonlar arasındaki ilişki olarak gerçekleşebileceği ileri sürülebilir. Türkçede durum sistemi morfolojik yolla sağlandığından dizimde söz dizimsel ögelerin dolayısıyla sözcüklerin yeri büyük oranda esnek ve değişkendir. Ancak bazı işlevsel nedenlerle ve özellikle sözlüksel eşdizimliliğin görüldüğü durumlarda sözcüklerin dizimde özellikle bir söz dizimsel konumu tercih ettiği görülür. (3)'te mahkemeye sözcük biçiminin vermek fiilinin ya hemen önündeki ya da hemen sonundaki söz dizimsel konumda bitişik kullanılması gerekir. Durum ekli ögelerin söz diziminde esnek olabilmesine karşın mahkemeye sözcük biçiminin yerinden oynamadığ $\breve{1}_{1}$ aksi halde cümlenin dil bilgisi-dışı olduğu anlaşılır (3b). Yine (4a)'da odada sözcük biçimi tutmak fiiline bitişik konumda yer almak zorundadır. odada sözcük biçiminin dizimdeki yeri değiştiğinde cümle dil bilgisel olmasına karşın anlamı diğeriyle aynı değildir (4b). $\mathrm{Bu}$ türden dil bilgisel eşdizimlerin Türkçede sözlüksel eşdizimlerle çoğunlukla iç içe olduğu, hatta çoğunlukla sözlüksel eşdizimliliğin bir sonucu olarak, bazen de küçük cümle (small clause) adı verilen söz dizimsel dönüşüm, bir başka ifadeyle sıradışı durum yükleme (exceptional case marker) ${ }^{3}$ süreçleriyle ortaya çıtığ rahatlıkla söylenebilir. (5a)'da ögretmen sözcüğünün bilmek fiiliyle bitişik konumda ve hemen fiilin önünde kullanılması zorunluluğu sıradışı durum yüklemenin gerçekleşmesinden kaynaklanmaktadır.

3a) Çay, Kaya'yı mahkemeye verdi.

3b)*Çay, mahkemeye Kaya’yı verdi

4a) Hirsizı odada tutuyorlar.

4b) ? Odada hirsizi tuttular.

5a) Ailesi onu öğretmen biliyor.

5b) *Ailesi öğretmen onu biliyor.

${ }^{3}$ Türkçe sıradışı durum yükleme için bk. Zidani-Eroğlu 1997 ve Özsoy 2001 iii) Bir sözcük ya da sözcük dizisinden oluşan grubun tercih ettiği ya da kaçındığı dil bilgisel/söz dizimsel işlevler

Türkçede üçüncü (iii) kategorinin bir sözlüksel unsur ile onun kullanılabileceği belirli bir söz dizimsel işlev arasındaki ilişki olarak gerçekleştiği söylenebilir. (6a)'da cümlenin dil bilgisel olabilmesi için acımak fiilinin iyilik ya da iyelik öbeği yapısında ve özne işlevinde söz dizimsel bir unsurla kullanılması gerekir. acımak fiili nesne ya da ikinci bir durum ekli söz dizimsel unsurdan kaçınır. Ancak vermek fiili nesne işlevindeki ögeyi özellikle tercih eder (7a), aksi durumda nesne dişındaki söz dizimsel işlevlerle aynı dizimde kullanıldığında cümle dil bilgisi-dışı olur (7bc).

6a) Canım yanıyor/ aciyor.

7a) Yaşlı adam sokaktaki çocuklara şeker verdi

7b) Yaşlı adam sokaktaki çocuklara *şekere verdi.

7c) *Yaşlı adam sokaktaki çocuklara ..... verdi.

Hoey'in (2005) dil bilgisel eşdizimliliğin özelliklerini belirlediği yukarıdaki anlayışının kendinden önce yazın alanında dil bilgisel eşdizimlilikle ilgili özellikle Fihrt (1957), Benson (1997), Hunston and Francis (2000) ve Croft (1991) vs. dilbilimcilerin görüşlerinin harmanlanmasından oluştuğu anlaş1lıyor. Firth'ün etkisiyle dil bilgisel eşdizimlilik biçimi olarak ele alınan üçüncü (iii) kategorinin başta istem dil bilgisi olmak üzere çeşitli dil bilimi kuramlarında üye yapısı (argument structure), istem (valency), rol yapisı (theta role), söz dizimsel kategoriler (syntactic categories) ve dil bilgisel ilişkiler ve roller (grammatical relations and roles) vs. kavramları altında fiilin söz dizimsel ve anlamsal yapısı açısından etraflıca ele alındığ̣ görülür. Hoey'in belirlediği üçüncü (iii) kategori dil bilgisel eşdizimlilikten ziyade söz dizimiyle ilgili olduğundan bu çalışmada diğer iki kategori dikkate alınacaktır. Bununla birlikte dil bilgisel eşdizimliliğin dillere özgü bir durum olması dillerin kendilerine özgü kategorilerinin belirlenmesine imkân verebilir. Bu bakımdan Türkçe fiillerin isimlerle birlikte kullanımında ortaya çıkan dil bilgisel eşdizim biçimlerinin kendine özgü yanları vardır. Dil bilgisel eşdizimliliğin dillere özgü yaklaşımlar geliş̧tirilerek araştırılması özgün dil bilgisel eşdizim biçimleri ve kalıplarının belirlenmesini kolaylaştıracaktır. Dil bilgisel eşdizim kalıplarının belirlenmesiyle isimlerin, fiillerin, sıfatların, edatların ve zarfların biçim ve anlam çifti olarak davranan dil bilgisel/ söz dizimsel yapıları da belirlenmiş olacaktır.

\section{Sözlükten Dil Bilgisine: Yarı Sözlüksel Unsurlar}

Dillerde içerik ve işlev sözcükleri olarak da adlandırılan sözlüksel ve dil bilgisel olmak üzere iki temel kategori vardır. Dillerde bazı dil birimleri ne sözlüksel unsurlar ne de dil bilgisel unsurlar içerisinde sınıflandırılabilir. Kimi dil birimlerinin sözcük ve dil bilgisi arasında yer aldığı, yarı sözlüksel ve yarı dil bilgisel kategorilerin özelliklerini taşıdığı, bu açıdan ayrı bir kategori oluşturduğu kabul edilir (bk.Corver and Riemsdijk, 2001). Nevalainen (2004), sözcük ile dil bilgisi arasındaki ilişki ve etkileşim ile dilbilgiselleşme arasında sıkı bir ilişkinin olduğunu, sözcük ve dil bilgisi arasındaki etkileşim sürecinin sözlüksel unsurları dil bilgisel unsura, dil bilgisel unsurları ise daha 
dil bilgisel bir unsura dönüştürdüğünü ifade eder. Yarı sözlüksel kategorilerin oluşmasında, yani kimi sözlüksel unsurların dil bilgisel unsur gibi davranmasında eşdizimlilik olgusunun etkisi vardır. Eşdizimsel kullanımı olan sözlüksel unsurlar sıklığa bağlı olarak sözlüksel içerik ya da işlevlerini kaybederek dilbilgiselleşir ve çeşitli dil bilgisel yapılara dönüşebilir. Örneğin Çalışkan (2014)'te zaman unsuruyla ilgili yapilan saptamalarda da görülebileceği gibi durum sözcüğü yarı sözlüksel ya da yarı dil bilgisel birer unsur olarak kabul edilebilir. durum sözcüğünün sözlüksel bir unsur olarak kullanılmakla birlikte belirli dil bilgisel kategori ve yapılarla dilbilgiselleşme sürecinde olduğu, çoğunlukla derlemde "mAsI durumunda" yapısıyla kullanıldığı görülür. zaman sözcüğü de benzer şekilde “-dIğI zaman” yapısında kullanılır. $\mathrm{Bu}$ sözlüksel unsurların kendisinden önce bir isim-fiil ve sıfat-fiil biçimbirimleriyle sıklıkla kullanılması dil bilgisel eşdizimlilikten kaynaklandığ 1 , dil bilgisel eşdizimliliğin sürecin sonunda sözlüksel unsurların dilbilgiselleşmesine yol açtığı söylenebilir. “-mAsI durumunda" yapısının kiplik işleviyle kullanıldığı ve şart kipinin işlevini gördügü söylenebilir (9b). "-dIğI zaman" yapısının ise "-dIğIndA" zarf-fiilinin işlevine karşılık geldiği ileri sürülebilir. Her ne kadar durum ve zaman sözcükleri bu yapılarda dilbilgiselleşse de sözlük unsuru olarak isim kategorisinde de kullanılmaya devam eder. durum ve zaman sözcüklerinin söz konusu dil bilgisel işlevlerde kullanılması onların dil bilgisel eşdizimlerinin olmasından ileri gelir. (8a) ve (9a)'da isim unsurunun sözlüksel özelliklerini kaybetmesinden ötürü dil bilgisel unsurlarla daha büyük yapıya dönüşerek dilbilgiselleştiği, prototip bir yapı olarak FïL + [-mAsI + DURUMUNDA] ve FİIL + [-dIğI + ZAMAN $]$ dil bilgisel eşdizim kalıplarının oluştuğu söylenebilir.

8a) Assur-masüi kararını göster-[mesi durumunda] bunları ödeyeceğini belirtmektedir.

8b) Assur-masüi kararını göster-ir-se bunları ödeyeceğini belirtmektedir.

9a) Güçlükle karşılaş-[tı̆̆ı zaman] içine kapanacak ya da kaçacaktır.

9b) Güçlükle karşılaş-tığında içine kapanacak ya da kaçacaktır.

Edatlar sözlüksel unsurlarla dil bilgisel unsurlar arasında yar1-sözlüksel unsurlara oldukça benzeyen bir kategoridir. Yarı sözlüksel unsurların, kimi sözlük birimi ve sözcük biçimlerinin fiillerle ya da diğer sözlüksel unsurlarla sıklık kullanımına bağlı olarak sözlüksel özelliklerini yitirdiği ve dilbilgiselleştiği söylenebilir. Dilbilgiselleşmenin dil bilgisel eşdizimliliğin bir ürünü olduğu rahatlıkla ileri sürülebilir. Bu bakımdan bazı sözcük biçimlerinin özellikle fiillerle sık kullanılması onların yarı sözlüksel birimlere dönüşmesine, sonraki aşamada ise, geleneksel olarak her ne kadar bir sözcük türü olarak kabul edilse de, edat işleviyle dilbilgiselleşmesine yol açtığı iddia edilebilir. Örneğin düşünmek fiilinin birliktelik sıklığı ve eşdizim kullanımları incelendiğinde en çok diye $e^{4}$ olarak, üzerinde, üzerine, göre, üstüne, şeklinde, hakkında vs. bazı edat ve sözcük

\footnotetext{
${ }^{4}$ TUD verilerine göre düşünmek fiilinin en sık birlikte kullanıldığ 1 unsur diye edatıdır. diye edatının diğer eşdizim özellikleri için ayrıca bk. Çalışkan, 2019.
}

biçimleriyle kullanıldığı görülür. $\mathrm{Bu}$, bir taraftan düşünmek fiiliyle bu unsurlar arasında dil bilgisel eşdizimliliğin oluşmasını sağlamış diğer taraftan olarak, üzerinde, üzerine, üstüne, hakkında sözcük biçimlerinin dilbilgiselleşmesine ve nihayetinde edat işleviyle kullanılmasına yol açmıştır ${ }^{5}$. Özellikle olarak sözcük biçiminin yarı sözlüksel unsur özellikleri gösterdiği, buna karşın dikkat çekici bir edatlaşma süreci yaşadığı söylenebilir.

10a) Okuyanlara da tesiri olur diye düşün-üyorum.

10b) Serbest piyasa kurallarına göre düşün-üyorsun dedi o.

10c) Her ne olursa okuması gerekir şeklinde düşünüyorum.

10d) Mutlaka böyle konular üstüne düşün-müşsündür.

\section{Dil Bilgisel Kalıpların Anlamı - Anlamın Dil Bilgisel Kalıpları}

Sözcük ile dil bilgisi arasındaki ilişki kadar dil bilgisi ile anlam arasında da bir ilişki vardır. Sözcükler dil bilgisini oluştururken dil bilgisinin de sözcüğün anlamını belirlediği ve belirli anlam kalıpları meydana getirdiği söylenebilir. Dolayısıyla sözcüklerin olduğu kadar dil bilgisel kalıpların da belirli anlamları vardır. Belirli anlamlar belirli dil bilgisel yapılarla belirli dil bilgisel yapılar da belirli anlamlarla ilgilidir. Bir sözcügün bir dil bilgisel yap1 ya da kalıpta kullanılabilmesi için sözcügün anlamının dil bilgisel yapının anlamıyla örtüşmesi ya da anlamlarının birbirine yakın olması gerekir. Örneğin (11a)'da söylemek fiili, FİIL $+(-\mathrm{dIk} /-\mathrm{AcAk})+$ IYELIKK + DURUM EKİ + FİIL kalıbında "bir düşünceyi ileri sürmek, iddia etmek, ortaya atmak (TS)" anlamında kullanılmıştır. Bu, dil bilgisel kalıbın çekirdek anlamının "bir düşünceyi ileri sürmek, iddia etmek" olduğu, sözcüğün anlamının kalıbın anlamıyla örtüştüğü anlamına gelir. Bu durumda, söz konusu dil bilgisel eşdizim kalıbında kullanılabilecek diğer fiillerin de bu kalıbın anlamını taşıdığı ileri sürülebilir. Örneğin (11b)'de düşünmek fiili söylemek fiiliyle bahsi geçen aynı dil bilgisel kalıpta kullanıldığı için aynı ya da benzer anlamları taşıdıkları, daha doğrusu kullanıldığı dil bilgisel kalıbın anlamını aldıkları ileri sürülebilir. $\mathrm{Bu}$, tersi açısından ise "bir düşünceyi ileri sürmek, iddia etmek, ortaya atmak" anlamının düşünmek ve söylemek fiillerinin de kullanıldığı söz konusu dil bilgisel kalıptan elde edilebileceği anlamına gelir. Bununla birlikte bir fiilin birden fazla dil bilgisel eşdizim kalıbı olabilir. Bir fiilin birden fazla dil bilgisel kalıbı varsa birden fazla da anlamı olması beklenir. Örneğin söylemek fiilinin "yapılmasını istemek (TS)" anlamı için yukarıda bahsi geçen dil bilgisi kalıbı kullanılamaz. Fiilin bu anlamı için FİIL + [-mA] + IYYELIK + DURUM + FİL dil bilgisel kalıbının kullanılması gerekir (12a). Bu dil bilgisel eşdizim kalıbında kullanılabilecek diğer fiillerin dil bilgisel kalıbın anlamından ötürü söylemek fiilinin bu anlamıyla da örtüşeceği söylenebilir. Bundan ötürü (12b)'de istemek fiilinin söylemek fiiliyle aynı kalıpta kullanıldığı için yakın bir anlam ifade ettiği rahatlıkla söylenebilir. Dil bilgisel

\footnotetext{
${ }^{5}$ Fiillerle kimi sözcük biçimleri arasında söz konusu dil bilgisel eşdizimlilik olması haklı olarak Türkolojide yaygın olarak kabul edilen edatların dışında farklı edatların olabileceği fikrini ortaya çıkarmış (bk. Boz, 2018)
} 
kalıbın anlamının sözcüğün anlamını belirlediğini en iyi ortaya koyan örneklerden biri beklemek fiilinin söz konusu yapıda "istemek" anlamiyla kullanıldığı (12c)'dir. beklemek fiili durağan fiil olmasına karşın (12c)'de dil bilgisel kalıbın anlamı dolayısıyla duygu (istemek) ve iletişim (söylemek) fiilleriyle aynı anlam ya da işlevde kullanılmıştır.

11a) Hececiler, kendilerinden sonra yeni bir edebî neslin yetişme-[diğ]- $\{\mathbf{i}\}-n-[\mathbf{i}]$ söylüyorlar.

11b) Hececiler, kendilerinden sonra yeni bir edebî neslin yetişme-[diğ $]-\{\mathbf{i}\}-n-[\mathbf{i}]$ düşünüyor.

12a) Doktor odadan çık-[ma]-\{m\}-[1] söyle-di.

12b) Polisler, köylülerin sıra halinde binanın dışına çık[ma]- $\{\mathbf{s}\}$-n-[1] iste-di.

12c) CEO'lar uzaktan çalışmanın daha yaygın hale gel[me]- $\{$ si $\}-n-[\mathbf{i}]$ bekli-yor.

Genellikle yakın anlamlı fiiller aynı dil bilgisel eşdizim kalıplarında kullanılır. Bununla birlikte nadiren aynı kavram alanına ve anlama sahip olmasına karşın kimi sözcüklerin dil bilgisel eşdizim kalıpları farklılaşabilir. demek ve söylemek aynı kavram alanına ve yakın anlama sahip olmasına karşın dil bilgisel eşdizim kalıpları farklıdır. demek fiili bir aşamalı dil bilgisel eşdizim kalıbında kullanılırken söylemek fiili üç aşamalı dil bilgisel eşdizim kalıbında kullanılır. söylemek söz diziminde isim kategorisi görevinde ve yükleme durumunda bir yan cümleyle eşdizimlenirken (13a), demek fiili bir iç cümleyle kullanılır (13b) ve söylemek fiilinin aksine adlaşmış (nominalization) bir yan cümleyle eşdizimlenmeyi reddeder (13c). Diğer taraftan aşağıda üç aşamalı dil bilgisel eşdizim bölümünde inceleyeceğimiz gibi söylemek fiili de bir iç cümleyle ve dIk ve -AcAk dişında sıfat-fiil kategorisindeki diğer biçimbirimlerle eşdizimlenmekten kaçınır. Aksi durumda cümle dil bilgisi dıșı olur (13d). Bu, ya fiillerin sözlüksel anlamlarının dil bilgisel kalıpların anlamlarıyla tam olarak örtüşmediği, dil bilgisel eşdizim kalıplarının muhtemel dil bilgisel işlevleriyle çakıştığı ya da belirli anlamların elde edilebilmesi için özellikle tercih edilen belirli bir kullanım normu olduğu anlamına gelir.

13a) Hececiler, kendilerinden sonra yeni bir edebî neslin yetişme-diğ-i-n-i söylüyorlar.

13b) Hececiler, ["Bizden sonra yeni bir edebî nesil yetişmedi."] dediler.

13c) *Hececiler, kendilerinden sonra yeni bir edebî neslin yetişme-diğ-i-n-i dediler.

13d) *Hececiler, "Bizden sonra yeni bir edebî nesil yetişmedi." söylediler.

Sözcüklerin nasıl birden fazla anlamı varsa dil bilgisel kalıpların da birden fazla anlamı vardır, dolayısıyla çok anlamlıdır. Sözcüklerin olası anlamları nasıl sözlüksel ve dil bilgisel bağlamın etkisiyle belirginleşiyorsa dil bilgisel kalıpların olası anlamlarının da aynı şekilde belirgin hale geldiği söylenebilir. Dil bilgisel eşdizim kalıplarının prototip kalıplardır ve oldukça geniş bir anlam alanını kapsadığ1 söylenebilir. Yukarıda söylemek ve düşünmek gibi FİIL + (-dIk/ -AcAk) + IYYELIK + DURUM EKİ + FİIL kalıbında kullanılan fiillerin "bir düşünceyi ileri sürmek, iddia etmek, ortaya atmak" anlamı kazanacağı ileri sürülmüştü. Ancak (11c)'de görmek fiili söylemek ve düşünmek ile aynı dil bilgisel kalıpta kullanıldığı halde söz konusu anlamı ifade etmez. görmek fiili söz konusu dil bilgisel kalıpta "anlamak, kavramak, sezmek" anlamıla yer alır.

11c) Olanlardan sonra annesinin haklı ol-[duğ $]-\{\mathbf{u}\}-n-[\mathbf{u}]$ gördü.

Dil bilgisel eşdizim kalıplarının çok anlamlılığı sözcüğün anlamıyla dil bilgisinin anlamının birleştirildiği alt prototip kalıplarla belirginleştirilebilir. $\mathrm{Bu}$, dil bilgisi kalıbının anlamını temsil edebilecek en iyi sözlüksel unsurun terkibiyle elde edilir. Bu, üst dil bilgisi kalıbındaki FïIL unsurunun yerine dil bilgisel kalıbın ve sözcüğün anlamını temsil edecek en iyi sözlüksel unsurun yerleştirilmesiyle elde edilir. Örneğin şimdiye kadar incelediğimiz söylemek, düşünmek, görmek fiillerinin aynı dil bilgisel kalıbı kullandığı ancak bunların aşağıdaki anlam temelli iki alt prototip kalıba tasnif edilebileceği ileri sürülebilir. Buna göre (i)'in söylemek, (ii)'nin ise görmek olmak üzere birer üyesi olduğu savunulabilir. Bu alt prototip kalıpların altında tasnif edilebilecek doğal olarak başka fiiller de vardır. Ancak bu çalışmada daha çok üst dil bilgisel kalıplar belirlenmiştir.

i) Fİ̈L + (-dIk/ -AcAk) + IYYELIK + DURUM EKİ + DÜŞÜNMEK

ii) FİIL + (-dIk/ -AcAk) + IYYELIK + DURUM EKİ + ANLAMAK

\section{Türkçe Dil Bilgisel Eșdizimliliğin Așamaları ve Dil Bilgisel Eșdizim Kalıpları}

Doğan (2019), yazın alanındaki dil bilgisel eşdizimlilik yaklaşımlarından, özellikle Benson (1997)'den hareketle Türkçede dil bilgisel eşdizimlerin çoğunlukla isimlerin isimlere, isimlerin fiillere, sifatların isimlere belirli edat ve durum ekleriyle bağlanması durumunda ortaya çıkan yapılara karşılık geldiğini, Türkçede sözlüksel eşdizimlilikle dil bilgisel eşdizimliliğin çoğu zaman iç içe geçtiği ve bir dereceye kadar birbirinden ayrı düşünülemeyeceğini ileri sürer. $\mathrm{Bu}$ değerlendirme, Türkçe dil bilgisel eşdizimliliğin önemli bir kısmını teşkil etmesine karşın bütününü yansıtmaz. Aksi halde Türkçe dil bilgisel eşdizimlilik durum kategorisiyle sınırlandırılmış ve sözlüksel eşdizimliliğin sahasına hapsedilmiş olur. Sözlüksel eşdizimlilik olmadan da kimi sözlüksel unsurlar belirli dil bilgisel birim, yap1 ve kategorilerle eşdizimlenebilir ve bu eşdizimden kimi işlevsel ve anlamsal ayrımlar ve kullanım normları ortaya çıkabilir. Dil bilgisel eşdizimlilik karmaşık örüntüleri olan dillere özgü bir durumdur ve diller arasında sayı, tür ve biçimi değişir. $\mathrm{Bu}$ bakımdan Türkçe dil bilgisel eşdizimliliği sözlüksel unsurların durum ekleri ve edatlarla birlikte kullanımı ve gerektirim ilişkisi olarak sınırlandırmak doğru olmaz. Dil bilgisel eşdizimliliğin dile özgü olması her dil için ayrı bir dil bilgisel eşdizimlilik belirlemesinin yapılmasını gerektirir. Türkçe dil bilgisel eşdizimlilik biçimleri doğal olarak diğer dillerden farklı ve karmaşık bir görüntü arz eder. Özellikle Türkçenin şekil bilgisel açıdan zengin olması farklı dil bilgisel eşdizimlilik tür ve biçimlerinin görünmesine yol açar. $\mathrm{Bu}$, dil bilgisel eşdizimliliğin üç aşamada Birinci Aşama Dil Bilgisel Eșdizimlilik, Íkinci 
Aşama Dil Bilgisel Eşdizimlilik ve ÜÇüncü Aşama Dil Bilgisel Eşdizimlilik şeklinde ele alınmasını gerektirir.

Bir sözcük ile dil bilgisel yapı ve kategoriler arasındaki çekim gücüyle oluşan gerektirim ve kısıtlllık ilişsisi, belirli dil bilgisel eşdizimlilik kalıplarında ortaya çıkar. Dil bilgisel eşdizimlerin çoğunlukla daha önceki çalı̧̧malarda sözlüksel eşdizim kalıpları olarak kabuk edilen 5 (beş) temel söz dizimsel yapı ve kategoride ortaya çıktığ söylenebilir: isim + isim, isim + fiil, slfat + isim, zarf + fiil, zarf + sıfat. Söz konusu söz dizimsel kategorilerden isim + fiil kalıplarında çok farklı ve zengin bir dil bilgisel eşdizimlilik örüntüsü ortaya çıkar. Bu kalıplar bundan sonraki incelemelerde dil bilgisel eşdizimlerin de etiketlenmesiyle yeniden düzenlenerek kullanılmıştır.

\subsection{Bir Aşamalı Dil Bilgisel Eşdizimlilik}

Bir aşamalı dil bilgisel eşdizimlilik çoğunlukla fiillerin isimlerle birlikte kullanımı sırasında söz dizimsel kategori olarak isim ya da isim öbeğinin fiillere belirli dil bilgisel kategori ve biçimbirimlerle, özellikle durum ekleri ve edatlarla doğrudan bağlandığı ve bunun bir kullanım normuna dönüştüğü sözlüksel dil bilgisi (lexicogrammatical) kalıplarını ifade eder. $\mathrm{Bu}$, yazın alanında morfolojik istem adı da verilen (bk. Doğan, 2011), fiillerin belirli dil bilgisel biçimbirimlerle ya da durum ekleriyle teşkil edilen söz dizimsel kategorileri yani ad öbeklerini (AÖ) talep etmesi şeklinde de tarif edilebilir. Bir aşamalı dil bilgisel eşdizimliliğin farklı gerçekleşme biçimleri vardır ve farklı kalıplarda ortaya çıkar. Bir aşamalı dil bilgisel eşdizimlerin yaygın biçimde göründüğü eşdizim kalıpları şunlardır:

\section{i) İSIM + DURUM EKLERI + FIIL}

Fiillerin birinci aşama dil bilgisel eşdizimlilik düzeyinde çoğunlukla durum ekleriyle eşdizimlendiği söylenebilir. Bunlar, sıklık kullanımına bağlı olarak çoğunlukla dilin ilk zamanlarında gelişmiş, fiillerin belirli bir anlamda ve işlevde sadece belirli durum eklerine gerek duymasıyla oluşan dil bilgisel eşdizim kalıplarıdır. Örneğin (14)'te gitmek fiilinin $e v$ ismiyle kullanımında yönelme durum ekini istemesi ve diğer durum eklerini dışlaması ya da kaçınması buna örnek gösterilebilir. Yine birinci aşamada (15)'te seyretmek fiilinin yükleme [-I] durum ekiyle, (1d)'da atlamak fiilinin ayrılma durum [-dAn] ekiyle, (17)'de ise bulunmak fiilinin bulunma durumu [-dA] ekiyle eşdizimlendiği söylenebilir. Bununla birlikte bir dizimde nasıl birden fazla sözlüksel eşdizim oluyorsa birden fazla dil bilgisel eşdizim de olabilir. (18)'te vermek fiilinin hem yönelme [-A] hem de yükleme [-I] durum ekiyle gerektirim ilişkisi olduğundan iki farklı dil bilgisel eşdizim kalıbının olduğu rahatlıkla söylenebilir. Bir aşamalı dil bilgisel eşdizimliliğin aynı zamanda temel söz dizimsel yapıları meydana getirdiği, dolayısıyla ad öbekleri şeklinde düşünüldüğünde bir aşamalı dil bilgisel eşdizim kalıplarının temel söz dizimsel yapıları ifade ettiği anlaşılır. Aşağıdaki bölümlerde de değinileceği gibi fiillerin farklı sözlüksel anlamları söz konusu olduğunda genellikle farklı bir aşamalı dil bilgisel eşdizim kalıpları ortaya çıkar ${ }^{6}$. Bu, sözcük ile dil bilgisinin birbirine ne denli sıkı sıkıya bağlı olduğunu gösteren önemli bir delil kabul edilebilir.

\footnotetext{
${ }^{6} \mathrm{Bu}$ konuda daha fazla için bk. Doğan, 2018.
}

14) Birlikte bekçinin evi-n-[e] git-tik

15) Turistler Boğaz-[1] seyred-iyor.

16) Çocuklar pencere-[den] atla-mış.

17) Bir dönem Paris-[te] bulun-du.

18) Yaşlı adam şeker-[i] çocuklar-[a] ver-di.

ii) $\{$ ISIM $\}+$ DURUM EKLERİ $\leftrightarrow$ FIIIL $\}$

Türkçede sözlüksel ve dil bilgisel eşdizimlilik çoğunlukla iç içe gerçekleştiğinden dil bilgisel eşdizim genellikle sözlüksel eşdizimliliğin bir parçası olarak ortaya çıkar. Örneğin (16)'da mahkemeye vermek bir sözlüksel eşdizim örneği olmasına karşın aynı zamanda bir dil bilgisel eşdizim örneğidir de. "mahkeme-y-e vermek" birleşmesinde mahkeme ile vermek arasında sözlüksel eşdizimlilik ilişkisi vardır. Bununla birlikte mahkeme ismi vermek fiiline yönelme durum ekiyle [-A] bağlanmak zorunda olduğundan ve söz konusu sözcüklerin birlikte kullanımı yönelme durum ekiyle kısıtlandığından aynı zamanda bir aşamalı dil bilgisel eşdizim örneğidir. İsim ile fiil unsurunun sözlüksel eşdizimli olduğu \{\} işareti kullanılarak \{İSIM $\}$ + DURUM EKİ $\leftrightarrow$ FİIL $\}$ şeklinde etiketlenebilir. Dil bilgisel eşdizim ile sözlüksel eşdizimin iç içe geçtiği bu durum, bundan sonra katışık eşdizim terimiyle anılacaktır. (i) ve (ii) numaralı dil bilgisel eșdizim kalıpları arasındaki temel birkaç fark vardır. İkincisinde (ii) sözlükselleşmenin etkisiyle ve derecesine göre durum ekininin özerkliğini kısmen yitirdiği, eklendiği sözcükle bütüncül ya kolektif hareket ettiği ve bir dereceye kadar içinde bulunduğu sözlüksel ve dil bilgisel yapıyla kalıplaştığı söylenebilir $(\mathrm{Bu}$ durum, $\leftrightarrow$ işaretiyle gösterilmiştir) . İlkinde (i) ise durum ekinin eklendiği sözcükle fiil arasında herhangi bir sözlükselleşmenin olmadığı, dolayısıyla dil bilgisel eşdizimin sözlüksel eşdizim kalıbında gerçekleşmediği, durum ekleri ile fiil arasındaki gerektirim ilişkisinin diğer sözlüksel unsurdan bağımsız gerçekleştiği, durum ekinin özerk davrandığı ve işlevini yitirmediği ileri sürülebilir (Bu durum, + işaretiyle gösterilmiştir).

19) Çay, Kaya-y-[1] mahkeme-y-[e] verdi.

iii) FïiL $+[\mathrm{mIşs} / \mathrm{mAk} \leftrightarrow$ FílL $]$

Fiillerin belirli fiilimsi ekleriyle birinci aşamada birbirini gerektirdiği ve kısıtladığı, bunun sonucunda belirli işlevsel ayrımların ortaya çıktığı kullanım normlarının oluştuğu görülür. (20)'de istemek fiili $-\mathrm{mAk}$ biçimbirimi ya da mastar ismiyle sıklıkla kullanılır ve bir aşamalı dil bilgisel eşdizimin oluştuğu anlaşılır (21). Benzer şekilde (22)'de bulunmak fiilinin $-m I s ̧$ biçimbirimiyle eşdizimlendiği dikkat çeker. Bu eşdizim kalıbında farklı fiiller söz konusu olduğunda farklı dil bilgisel eşdizimler oluşabilir. Özellikle belirli dil bilgisel işlevleri ifade edebilmek için diğer fiilimsi ekleriyle oluşmuş dil bilgisel eşdizimlere de rastlamak mümkündür. gitmek fiili (23)'te k1lınış kategorisinin ifadesi için -Ip zarf-fiiliyle eşdizimlendiğ i söylenebilir. Bu yapılarda fiilimsi biçimbirimlerinin temel işlevlerini ve özerkliğini kaybettiğini, sözlüksel unsurla kalıplaşarak ayrı bir bütüncül şekil oluşturduğunu söyleyebiliriz. Örneğin (24)'te -tI-/ -dI- geçmiş zaman işaretleyicisi olmasına rağmen bu işlevini yitirmiş gitmek fiiliyle tezlik ifaden bir işlevde kullanılmıştır. Ne kadar sözcük varsa o kadar da dil bilgisi olduğunu dikkate alırsak 
bu kalıpta yer alan fiile göre farklı dil bilgisel eşdizimler rahatlıkla oluşabilir. Bundan ötürü bu kalıbın kesin sınırlarını çizmek pek de mümkün değil.

20) Ama sadece şunu söyle-[mek] isti-yorum.

21) Şimdi, tanımdaki kimi kavramları aç-[mak] gerek-iyor.

22) Şimdi bu talihsiz evreye gir-[miş] bulun-uyoruz.

23) Babamın emekli maaşıyla geçin- [ip] git- tim işte.

24) Şimdi, temelli mi yani, çek-[ti] git-ti mi?

iv) EDAT + FİIL

Fiillerin edatlarla birliktelik kullanımı ve karşılıklı gerektirim ilişkisiyle oluşan yapılar da bir aşamalı dil bilgisel eşdizimliliğin diğer gerçekleşme biçimlerindendir. sormak fiilinin derlemden sıklık sorgusu yapıldığında birlikte en sik kullanıldığı unsurun diye edatı olduğu görülür $^{7}$ (25). Yine gelmek fiilinin sıklıkla kullanıldığ unsurlardan biri gibi edatıdır (26). Bu unsurların sıklıkla birlikte kullanımından belirli anlamları ve işlevleri ifade eden kullanım normlarının ve yapıların oluştuğu söylenebilir. gibi ve gelmek sözcükleri arasındaki gerektirim ve kısıtlılık ilişkisinden epistemik kiplik işaretleyen bir aşamalı dil bilgisel eşdizim yapısının oluştuğu anlaşılır. Daha önce de ifade edildiği gibi düşünmek fiilinin birliktelik sıklığı incelendiğinde en çok diye ${ }^{8}$ ve göre edatlarıyla kullanıldığı ve bir aşamalı dil bilgisel eşdizimlerin oluştuğu görülür. Ayrıca düşünmek fiilinin olarak, üzerinde, üzerine, üstüne, hakkında sözcük biçimleriyle de çok sık kullanıldığg ve bunun bahsi geçen sözcük biçimlerinin edat işleviyle kullanılmasına ve nihayetinde dilbilgiselleşmesine yol açtığı söylenebilir9

25) "Babacığım, kimdi onlar?" diye sor-du.

26) Önümden geçip yok olup gidecek gibi gel-di.

Edat ile fiilin dil bilgisel eşdizim kullanımında fiiller farklı çekim şekillerine, bir başka deyişle sözcük biçimlerine duyarlılık gösterebilir. Örneğin göre edatının değişmek fiiliyle sıklık kullanımı derlemden sorgulandığında fiilin geniş zaman ve şimdiki zaman 3. tekil şahıs şeklinin göre ile dil bilgisel bir eşdizimlilik gösterdiği anlaşılır (27). Derlem sorgusunda fiilin "değişir" biçimiyle birliktelik kullanım sıklığı 363 iken fiilin "değişti” ya da değişecek" şekliyle birlikte kullanım sıklığı sadece 1 (bir) şeklindedir. Fiilin anlamları farklı dil bilgisel eşdizimlerin, dolayısıyla farklı dil bilgisel yapıların oluşmasına sebep olur. başlamak fiili birinci aşamada çoğunlukla yönelme durum ekiyle eşdizimlenirken fiilin farklı anlamları söz konusu olduğunda farklı bir dil bilgisel eşdizimlerin, dolayısıyla da farklı dil bilgisel yapıların oluşmasına yol açar. (28a-b)'de başlamak fiilinin sonra ve ile edatlarıyla dil bilgisel eşdizim oluşturduğu aksi durumda cümlenin dil bilgisel

\footnotetext{
${ }^{7}$ Derlemde sıklığ en yüksek diğer kullanım soru sözcüğüyle olan soru sormak sözlüksel eşdizimidir. (22b) ancak fiilin "diye" edatıyla dil bilgisel eşdizimi diğerinden 36 kat daha fazladır.

${ }^{8}$ TUD verilerine göre düşünmek fiilinin en sık birlikte kullanıldığg unsur diye edatıdır. diye edatının diğer eşdizim özellikleri için ayrıca bk. Çalışkan, 2019.

${ }^{9}$ Fiillerle kimi sözcük biçimleri arasında söz konusu dil bilgisel eşdizimlilik olması haklı olarak Türkolojide yaygın olarak kabul edilen edatların dışında farklı edatların olabileceği fikrini ortaya çıkarmış (bk. Boz, 2018)
}

olmayacağı rahatlıkla söylenebilir. Söz konusu eşdizimler genel olarak EDAT + FİIL şeklinde ifade edilebilecek bir yapının ortaya çıkmasını sağlamıştır. Ancak bu noktada tekrar edatların da kendi bağımlı unsurlarıyla ayrıca dil bilgisel eşdizim yapıları kuracağı unutulmamalıdır. Örneğin göre edatının dil bilgisel eşdizimi de dikkate alındığında yapının İSIM + DURUM EKİ + EDAT + FİIL şeklinde genişlediği ve birleşik eşdizim ${ }^{10}$ adını verdiğimiz dil bilgisel eşdizim türünün oluştuğu söylenebilir.

27) Şiddeti kişinin içinde bulunduğu durum-a göre değ-ișir.

28a) Kasabanın kenar mahallelerin-den sonra bir mezarlık başlardı.

28b) Şiirimiz, milletimizin Anadolu'daki teșekkülü ile başlar.

v) CÜMLE + FİIL

Bir aşamalı dil bilgisel eşdizimler her zaman belirli sözlüksel unsurların belirli dil bilgisel biçimbirimleri tercih etmesi ve birbirini gerektirmesiyle oluşmaz. Bazen fiiller bir söz dizimsel kategori olarak aynı dizimde bir cümleyle eşdizimlenebilir. Derlem sorgusu yapıldığında demek fiilinin bitimli iç cümlelerle devamlı birlikte kullanıldığı ve bu sıklık kullanımından bir dil bilgisel normun oluştuğu söylenebilir.

\section{9) "Sen yalnız onun yerini bana göster!" dedi.}

vi) $[$ İSIM + ÇOKLUK $]+$ Fİ̈L

Dil bilgisel eşdizimlilik her zaman sadece belirli dil bilgisel kategori ya da işaretleyicilerle olan birliktelik kullanımlarını ifade etmez. Fiillerin belirli sözcük biçimleriyle de gerektirim ve kısıtlılık ilişkisi olabilir. $\mathrm{Bu}$ bakımdan bir aşamalı dil bilgisel eşdizimliliğin diğer bir biçimi fiillerin sözcük biçimleriyle, özellikle de isimlerin çokluk şekliyle eşdizimlendiği yapılardır. $\mathrm{Bu}$ yapılarda, fiilin çokluk ekiyle eşdizimlenmesinden daha ziyade isimlerin belirli sözcük biçimleriyle eşdizimlendiğine dikkat etmek gerekir. Örneğin (30)'da dilemek fiili başarı ve muvaffakiyet isimlerinin çokluk biçimiyle eşdizimlenmiştir. Yine (31)'de methiye ve döktürmek sözcükleri arasında da aynı durum söz konusudur. Aynı zamanda bir sözlüksel eşdizim örneği olan methiyeler döktürmek yapısında isim unsurunun çokluk biçimiyle çekimlenmesi iki aşamalı dil bilgisel eşdizimliliğin gereğidir. methiye isminin teklik biçimiyle kullanımı sözcük birleşmesini dil bilgisel olmaktan uzaklaştırır (31c). Söz konusu kalıpların bu hâlleriyle sözlükselleştiği, hatta deyimleştiği dikkat çekmektedir. Bir aşamalı dil bilgisel eşdizimlerdeki sözcük biçimleri arasındaki kısıtlılık ve gerektirim ilişkisi söz konusu unsurları köşeli parantez [ ] içine almak suretiyle etiketlenebilir.

30) Şimdiden bașarı-[lar]/ muvaffakiyet-[ler] dili-yorum.

31a) Nazım ... bu defa da ona methiye-[ler]-ø döktürmüş.

31b) *Nazım ... bu defa da ona methiye-ø döktürmüş.

31c) *Nazım ... bu defa da ona methiye-[ler]-i döktürmüş.

\footnotetext{
${ }^{10}$ Birleşik eşdizim, farklı sözcük türlerinin dil bilgisel ya da sözlüksel eşdizim kullanımlarının birleşmesinden oluşur. İki dil bilgisel eşdizim birleşebileceği gibi iki sözlüksel eşdizim de birleşebilir.
} 
vii) $\{$ İSiM $\}+\{[$ FiilL $]\}$

İsimlerin fiillerin olumsuzluk ya da yeterlik ifade eden sözcük biçimleriyle eşdizimlenmesi de bir aşamalı dil bilgisel eşdizim örneği olarak kabul edilebilir. (32a)'da fiil isim unsuruyla ancak olumsuz sözcük biçimiyle kullanılabilir. Aksi durumunda fiillerin olumlu sözcük biçimlerinin dil bilgisel bir kullanım olmadığı görülür (32b). Benzer şekilde (33a)'da brrakmak fiilinin olumsuz sözcük biçimi isimle önemli bir kullanım kısıtllılı̆ 1 oluşturur. $\quad \mathrm{Bu}$ yapıların sözlüksel ve dil bilgisel eşdizimliliğin iç içe geçtiğini ve yüksek kalıplaşma düzeyine eriştiğini, bu nedenle sözlükselleştiklerini söyleyebiliriz. Fiillerin olumsuz sözcük biçimlerinin isim unsuruyla aynı zamanda sözlüksel eşdizim olduğu \{\} işaretiyle etiketlenmiştir.

32a) Güvenebileceği çare kal-[ma]-mıştı.

32b) Güvenebileceği çare * kal-mıştı.

33a) Selda'nın kendisine soru sormasına firsat birak-[ma]-dı.

33b) *Selda'nın kendisine soru sormasına firsat bırak-tı.

viii) İSIM + DURUM EKİ + İSIM

İsimlerin isimlerle birleşmelerinde de bir aşamalı dil bilgisel eşdizim oluşabilmektedir. İsimler diğer isimlerle söz diziminde kullanılırken farklı durum ekleriyle kısıtlanırlar. Örneğin yatkınlık ismi çoğunlukla yönelme durum ekiyle kullanılır. Bazen bu eksiz yükleme durumunu da talep edebilir. Özellikle fiilden türemiş farklı isimler farklı durum ekleri ve edatlarla çeşitli dil bilgisel eşdizim örüntüsü oluşturabilirler.

34a) Sanat-[a] yatkınlığı olanlara ücretsiz eğitim verilmiştir.

34b) Belki sanat-[ø] yatkınlığı keşfedilmemiş, yatkınlı̆ğ belirlenmemiş insan vardır.

ix) İSIM + DURUM EKİ + SIFAT

Sifatlar farklı durum ekleriyle eşdizimlenebilir. Derlem sorgulandığında sorumlu sıfatının büyük oranda belirli anlamların ifadesi için ayrılma durum ekiyle kısıtlandığ görülür. $\mathrm{Bu}$, sorumlu sıfatının -dAn biçimbirimine duyarlı olduğu anlamına gelir (35a). Sifatlar, farklı durum ekleriyle çeşitli dil bilgisel eşdizim örüntüleri oluşturabilirler. yakın sözcüğü sıfat görevinde kullanıldığında anlamına bağlı olarak yönelme durum biçimbirimiyle eşdizimlenir (35b).

35a) Kuzey ve güneyinde kendi içişlerin-[den] sorumlu iki ayrı parlamento vard.

35b) Demirören'e rakip olan diğer adaylar-[a] yakın gruplara mensup oldukları belirtiliyor.

\section{x) EDAT + SIFAT}

Sözcüğün farklı anlamları söz konusu olduğunda farklı dil bilgisel eşdizim örüntüsü oluşabilir. Yukarıda ayrılma durumuyla dil bilgisel eşdizimlilik örüntüsü olan sorumlu sıfatının derlem sorgusunda özellikle yüklemcil görevde kullanıldığında karşı edatıyla birlikte en sık kullanıldığı ve başka bir dil bilgisel eşdizimlilik örüntüsü oluşturduğu görülür (36).

36) Hükümet meclise karşı değil, kabinenin üyeleri tek tek padişaha [karşı] sorumlu-durlar.
Yine gerekli sözcüğü bir sıfat ve zarf olarak için edatıyla çok sık eşdizimlenmektedir. Derlemde gerekli sözcügünün en fazla kullanımı için edatıyla gerçekleşmektedir.

37) İnsanoğlunun yaşaması [için] gerekli maddi gıdaların en önemlisi tatlıdır.

\section{xi) İSIM + DURUM EKİ + EDAT}

Edatlar da isimlerle birlikte kullanılırken belirli durum ekleriyle eşdizimlenirler. için edatı zamirlerle birliktelik kullanımında ilgi durum ekiyle kısıtlanır (38a). için edatı birinci aşamada fiilimsilerle anlama duyarlı biçimde kimi zaman sıfat-fiil biçimleriyle kimi zaman da isim-fiil biçimlerinden ise sadece $-\mathrm{mAk}$ biçimbirimiyle dil bilgisel olarak eşdizimlenebilir. için edatı (38b)'de birinci aşamada iyelik kategorisiyle, ikinci aşamada sifat-fiil ile eşdizimlenirken (38c)'de yalnızca -mAk biçimbirimiyle eşdizimlenmiş̧ir. Bu her edatın ayrı bir dil bilgisel eşdizim kalıbının olduğu anlamına gelir ${ }^{11}$.

38a) Siz- $\{$ in $\}$ için bir kitap getirdim.

38b) Yemeği sevme-[diğ]-\{i\} için yiyemedi.

38c) Sınavı kazanabil-[mek] için çalışıyor.

\section{2. İki Aşamalı Dil bilgisel Eşdizimlilik}

İki aşamalı dil bilgisel eşdizimlilik bir sözlüksel unsurun birden fazla dil bilgisel unsur ya da kategoriyle ayn dizimde sıklıkla birlikte kullanılmasının etkisiyle aralarında kısıtlılık ve gerektirim ilişkisinin oluştuğu, bundan belirli işlevsel ve anlamsal ayrımların ortaya çıktığı dil bilgisisözcük birleşmelerini ifade eder. Örneğin fiiller çoğunlukla birinci aşamada belirli durum ekleriyle eşdizimlenirken ikinci aşamada durum eklerinden önce başka dil bilgisel unsur ya da kategorilerle bir kullanım normu oluşturacak şekilde sıklıkla birlikte kullanılır. İki aşamalı dil bilgisel eşdizimliliğin de iki farklı şekilde ortaya çıktığ söylenebilir.

i) FIIL + [-mA $]+$ DURUM EKİ + FIIIL

İlki, fiilin birinci aşamada bir durum işaretleyicisiyle ikinci aşamada ise başka bir dil bilgisel kategori ya da işaretleyiciyle, çoğunlukla da $-\mathrm{mA}$ isim-fiil ekiyle adlaştırılan yan cümle tamlayıcısıyla sıklıkla birlikte kullanıldığ yapılardır. İkinci aşama dil bilgisel eşdizimden ötürü durum ekli isim kategorisi kendi içinde ayrıca bir öbek yapı, yani isim-fiil öbeğidir. (39a) ve (40a)'da başlamak ve düşünmek fiillerinin ilk aşamada yöneleme durum ekiyle ikinci aşamada ise $-\mathrm{mA}$ işaretleyicisiyle teşkil edilen isim-fiil yan cümle tamlayıcisiyla gerektirim ve kısıtllık ilişkisinin olduğu, $-\mathrm{mA}$ dışında isim-fiil kategorisinin diğer işaretleyicileriyle birliktelik kullanımının ise dışlandığı görülür (39b-40b). Bu fiillerin belirli işlev ve anlamları ifade etmek üzere ikinci aşamada isim-fiil yan cümleleriyle kullanım kısıtllılığının olduğu ve bunun bir kullanım normuna dönüştüğu rahatlıkla iddia edilebilir.

39a) Her öğlen ve akșam yanlarına git-[me]-y-[e] başladim.

39b) *Her öğlen ve akşam yanlarına git-iş-e başla-dım.

${ }^{11}$ Edatların oluşturduğu dil bilgisel yapılar hakkında daha fazla bilgi bk. Doğan 2014, Boz 2018. 
40a) Bu konuda seminerler yap-[ma]-y-[1] da düşün-dük.

40b) *Bu konuda seminerler yap-[1ş]-[1] da düşün-dük.

ii) Fİ̈L + [-mA] + IYYELİK + FİIL

Sınırlı sayıda fiillerin, özellikle gerekmek fiilinin isim-fiil biçimbirimlerinden - $\mathrm{mA}$ ile sonra da iyelik kategorisiyle iki aşamada eşdizimlendiği ve bu kullanımdan kiplik anlamların ortaya çıktığı ileri sürebilir. Bununla birlikte gerekmek fiili (41b)'de bir aşamalı eșdizim kalıbında kullanılmıştır. $\mathrm{Bu}$ iki kullanım arasında yükümlülüğün farklı derecelerinin anlatıldığ 1 söylenebilir. (41b)'nin (41a)'ya göre yükümlüğünün daha yüksek olduğu ve koşulların gerektirdiği bir yükümlülügüün dile getirildiği söylenebilir. (41b)'de ise konuşurun öngördüğü ve derecesinin daha düşük olduğu bir yükümlülükten söz edildiği ileri sürülebilir.

41a) Şimdi sana bir şey açıkla-[ma]-[m] gerek-iyor.

41b) Şimdi kamuoyuna açıklama yap-[mak] gerek-iyor.

iii) $\{$ İSIM $\}+$ İYELIKK + DURUM EKİ+ $\{$ FIIIL $\}$

İki aşamalı dil bilgisel eşdizimliliğin ikincisi, karışık eşdizim adını verdiğimiz üç farklı yapının sözlüksel eşdizim, dil bilgisel eşdizim ve öbek yapının iç içe gerçekleştiği eşdizim kalıplarıdır. Karışık eşdizimler, fiilin birinci aşamada durum işaretleyicisiyle, ikinci aşamada diğer dil bilgisel kategori ya da işaretleyicilerle birliktelik kullanımın kısıtlandığı, fiilin aynı zamanda isim unsuruyla sözlüksel eşdizimlilik ilişkisinin bulunduğu, bununla birlikte sözlüksel eşdizimin isim unsurunun başka bir sözcükle öbek ilişkisinin de olduğu kalıpları ifade eder. Örneğin (42a)'da gelmek fiili akıl ismiyle sözlüksel eşdizimlidir. akll ismi gelmek fiiline birinci aşamada yönelme durumuyla, ikinci aşamada ise iyelik kategorisiyle eşdizimlenir. İkinci aşama dil bilgisel eşdizimden ötürü isim unsuru kendi içinde ayrıca bir öbek yapı, yani iyelik öbeğidir. akıl ve gelmek unsurlarının birliktelik kullanımları ancak bu kısıtlılık ve gerektirim şartları altında mümkündür, aksi durumda kabul edilebilir bir sözlüksel ve dil bilgisel yapı olmaz (42b). Bununla birlikte (42a-c)'te gelmek fiilinin ikinci aşamada belirli bir iyelik işaretleyicisiyle değil iyelik kategorisinin tümüyle bir kullanım kısıtlılığı vardır.

42a) Bir başka anı daha (benim) $a k l$-1- (m)-[a] gel-di.

42b) *Bir başka anı daha (bizim) akl-a gel-di.

42c) Bir başka anı daha (bizim) $\underline{a k l-1-(\mathbf{m ı z})-[\mathbf{a}] \text { gel-di. }}$

Sözlüksel eşdizimliliğin sözlükselleşme derecesi yükseldikçe dil bilgisel eşdizim kısıtlılığı artar. (43)'te varmak fiilinin fark ismiyle iki aşamalı eşdizim kullanımında iyelik kategorisinin tümüyle değil sadece üçüncü tekil iyelik işaretleyicisiyle kısitlandığı görülür. Aynı durum anlam ve gelmek unsurlarının birliktelik kullanımında da ortaya çıkar (44). Bu tür örnekleri artırmak mümkündür. Örneğin oynamak fiili birinci aşamada vasıta durum ekiyle eşdizimlenirken ikinci aşamada iyelik ekiyle de eşdizimlenmesi gerekir (45a). Aksi durumda cümle dil bilgisel olmaktan çıkar (45b). Bu onun iki aşamalı dil bilgisel eşdizim kalıbı olmasından ileri gelir. İyelik eki ancak iyeliğin diğer alamorflarıyla değiştirilebilir. Bu dil bilgisel eşdizim kısıtlılığının sözlüksel eşdizimliliğin etkisiyle meydana geldiği söylenebilir. Sözlüksel unsurların kullanımı dil bilgisel kategorinin kendisiyle ve tüm işaretleyicileriyle kısıtlandığında ( ), dil bilgisel kategorinin sadece bir işaretleyicisiyle kısıtlandığında ise [ ] ile etiketlenebilir.

43) Çocuklar (bazı doğa olaylarının) fark-[1]-n-[a] var-ır, gözlem yapar ve araştırırlar.

44) İletişim süreci açısından üretilen her bilgi, (bir ileti) anlam-[1]-n-[a] gel-mektedir.

45a) İçeride bu milletin hayat-[1]-y-[la] oyna-mak isteyen düşmanlar var.

45b) *İçeride hayat-[la] oyna-mak isteyen düşmanlar var.

iv) $\{[$ İSIM + ÇOĞUL EKİ $]\}+$ DURUM EKİ + \{FİIL $\}$

İki aşamalı dil bilgisel eşdizimliliğin farklı gerçekleşme biçimlerinden bir diğeri de çokluk ekiyle olanıdır. (46a)'da taşımak fiili bir aşamalı dil bilgisel eşdizimlilik açısından yükleme durumuyla sıklıkla kullanır. Ancak taşımak fiilinin dil bilgisel olabilmesi sadece birinci aşama eşdizimin sağlanmasına bağlı değildir. İkinci aşama dil bilgisel eşdizimin de yerine getirilmesi gerekir (46b). Yine (47a)'da dağ ve düşmek sözcükleri arasında da aynı durum söz konusudur. dăg isminin teklik biçimiyle kullanılması dil bilgisel olmaz, olsa bile farklı bir anlam söz konusu olur (47b). düş-[ler]- [e] dalmak örneğinden de hareketle söz konusu dil bilgisel eşdizimlerin çoğunlukla sözlükselleştiği, hatta deyimleştiği söylenebilir.

46a) Avrupa, parasal birlik için uygun şart-[lar]-[1] taşımiyor.

46b) *Avrupa, parasal birlik için uygun şart-[1] taşımıyor.

47a) Alp ozan almış sazı ele dağ-[lar] -[a] düş-müş, diyar diyar gezip türkü yakarmış.

47b) *Alp ozan almış sazı ele dağ-[a] düş-müş, diyar diyar gezip türkü yakarmış.

v) $\{$ İSIM $\}+$ DURUM EKLERİ + [FİIL]

İki aşamalı dil bilgisel eşdizim kalıplarında bir sözlüksel unsur belirli sözcük biçimleriyle, genellikle de fiillerin olumsuz ve yeterlik şekilleriyle kısıtlanır. Aksi durumda fiillerin olumlu sözcük biçimleriyle kullanımı dil bilgisel olmaz. Bu yapıların çoğunlukla sözlüksel ve dil bilgisel eşdizimliliğin iç içe geçtiği ve yüksek kalıplaşmanın olduğu, bu nedenle birleşmenin bütününün sözlükselleştiğini söyleyebiliriz. Örneğin akıl ve çıkarmak sözcük biçimleri belirli sözcük biçimleriyle birbirini gerektirir ve kısıtlar (48a). Birinci aşamada fiilin olumsuz biçimiyle, ikinci aşamada ise ayrılma durumuyla [-dAn] dil bilgisel kısıtlılığın oluştuğu söylenebilir. Aksi durumda dil bilgisel olmayan durumlar ortaya çıkar (48b). Bu dil bilgisel eşdizimlilik türünde ikinci aşama dil bilgisel eşdizim her zaman durum ekleriyle sağlanmaz. Bazen farklı dil bilgisel işaretleyicilerle de ikinci aşama eşdizimliliğin sağlandığ 1 görülür. Örneğin (49a)'da ikinci aşama eşdizimlilik iyelik işaretleyicisiyle sağlanmıştır. Ancak bu sözcük biçimleri sözlüksel eşdizim içinde kalıplaşmış biçimde kullanıldığından özerkliklerini çoğunlukla kaybeder ve kalıplaşmış şekilde kullanılır.

48a) Patrikhane'nin bu tavrı hiç akıl-[dan] çıkarıl-[ma]malıdır. 
48b) *Patrikhane'nin bu tavrı akıl-[dan] çıkarıl-malıdır.

49a) Ortada çözümlenmesi gereken bir sorun yoksa arayışın da bir anlam-[1] kal-[maz].

49b) *Ortada çözümlenmesi gereken bir sorun yoksa arayışın da bir anlam-[1] kal-ır.

\section{3. Üç Aşamalı Dil bilgisel Eşdizimlilik}

Fiiller belirli anlam ayrımları ortaya çıkaracak şekilde üç aşamada üç farklı dil bilgisel kategori ve işaretleyiciyle aynı dizimde sıklıkla birlikte kullanılabilir. Üç aşamalı dil bilgisel eşdizimlerin en az iki öbek yapı içerisinde fiilin sırasıyla durum, iyelik öbeği, sıfat-fiil ya da isim-fiil yan cümleleriyle birliktelik kullanımından ortaya çıktığ söylenebilir. Örneğin düşünmek fiili derlemden sorgulandığında ilk aşamada bir durum ekiyle, ikinci aşama bir iyelik ekiyle, üçüncü aşamada ise bir sıfat-fiil ekiyle eşdizimlenir (46a). Başka bir deyişle fiilin kullanımı yükleme durum ekli iyelik öbeği yapısında bir sıfat-fiil yan cümle tamlayıcısıyla kısıtlanır. Bu aşağıdaki dil bilgisel eşdizim kalıbını ortaya çıkarır.

50a) Nadya, uzun bir yolun sonuna gel-[diğ $]-\{\mathbf{i}\}-n-[\mathbf{i}]$ düşündü.

i) Fİ̈L + (-dIk/ -AcAk) + İYELİK + DURUM EKİ + FİIL

Üç aşamalı bu dil bilgisel eşdizim kalıbının sıklık kullanımının ve kısıtlılığın etkisiyle belirli fiillerin çevresinde oluştuğu rahatlıkla ileri sürülebilir. Örneğin görmek fiili bu üç aşamalı dil bilgisel eşdizim kalıbında kullanılabilirken (51a) gitmek fiilinin bu yapıda kullanılmasının pek mümkün olmadığını söyleyebiliriz. gitmek fiilinin kullanıldığ 1 dil bilgisel eşdizim kalıbında da görmek fiilinin kullanılamayacağını ileri sürülebilir. Fiillerin bu kullanım kısıtlılığ 1 ve normundan belirli anlamların ya da anlam kalıplarının oluştuğu söylenebilir. Örneğin görmek fiilinin Türkçe Sözlük’teki “Belirli bir zamanın içinde bir olaya tanık olmak, yaşamak" anlamıyla üç aşamalı dil bilgisel eşdizim yapısında kullanılması gerekir (52a). Ancak (52b)'de başka bir dil bilgisel eşdizim kalıbında "Göz yardımıyla bir şeyin varlığını algılamak, seçmek" anlamında kullanıldığı anlaşılır. düşünmek fiili de benzer şekilde (51a)'da söz konusu üç aşamalı dil bilgisel eşdizim kalıbında kullanılırken (51b)'de aynı fiil anlam farkıyla FİIL+ [-mA-] + DURUM EKİ + FİIL olarak etiketlediğimiz iki aşamalı dil bilgisel eşdizim kalıbında başka işaretleyicilerle birlikte kullanır. düşünmek fiili gerçekleştiği dil bilgisel eşdizim kalıbının etkisiyle (51a)'da "sanmak, farzetmek, aklından geçirmek" anlaminda kullanılırken (51b)'de "tasarlamak, planlamak" anlamını kazanmıştır.

51a) Nadya, uzun bir yolun sonuna gel-[diğ $]-\{\mathbf{i}\}-n-[\mathbf{i}] d \ddot{u} s ̧ \ddot{u} n-$ dü.

\section{1b) Bu konuda seminerler yap-[may]-[1] da düşün-dük.}

52a) Hülya ile salıncakta sallanırken [postacının bizim eve doğru gel-dĭg $]-\{\mathbf{i}\}$-n-[i] gör-düm.

52b) Dağdaki sular gibi uyanıktım hep sen-i gör-düm.

$\mathrm{Bu}$ dil bilgisel eşdizim kalıbında üçüncü aşamada -dIk sıfat-fiiliyle eşdizimlenen fiillerin çoğunluğu aynı zamanda aynı kategorideki -AcAk biçimbirimiyle de eşdizimlenebilir. Örneğin bilmek ve söylemek fiilleri her iki biçimbirimle de kullanılmıştır (53-54). Ancak bu, görünüş (aspekt) farklılıkları bir yana anlamsal bir fark oluşturmamıştır.

53a) Bu sersemliğim yüzünden başımı belaya sok- [acă̆]-1$\{\mathbf{m}\}$-[1] bil-iyordum.

53b) Tehlikeli bir iş yap- [tı̆g]- $\{\mathbf{1}\}-n-[\mathbf{l}]$ bil-iyordu.

54a) Türkiye'nin hastaların dertlerine şifa arayacağı merkez haline gel-[eceğ]- $\{\mathbf{i}\}$-n-[i] söyle-di.

54b) Şenol'la 1 yıllığına anlaşma sağlan-[dı̆̆ $]-\{\mathbf{1}\}-n-[\mathbf{1}]$ söyle-di.

ii) Fİ̈L + [-mA] + IYYELIKK + DURUM + Fİİ

Kimi fiiller özellikle istemek, dilemek vs. üş aşmalı dil bilgisel eşdizim kalıplarında kullanılır. Üçüncü aşamada $\mathrm{mA}$ isim-fiil biçimbirimiyle, öncesinde ise iyelik ve durum ekiyle eşdizimlenir. $\mathrm{Bu}$ dil bilgisel eşdizim kalıplarıyla emir, istek gibi kiplik anlamlarının sağlandığı söylenebilir.

55) Polisler, köylülerin sıra halinde binanın dışına çık[ma]-\{sı $\}-n-[1]$ iste-di.

56) Doktor odadan çık-[ma]-\{m\}-[1] söyle-di.

57) 28 Mart mahalli seçim sonuçlarının ülkeye hayırlı ol[ma]- $\{$ sı $\}$-n-[1] dile-di.

iii) $\{$ İSIM $\}+$ IYYELİK + DURUM + \{[FİİL $]\}$

Üş aşamalı dil bilgisel eşdizim kalıplarında dil bilgisel kategorilerin sözcük biçimleriyle, özellikle de fiilin olumsuz biçimiyle kullanım kısıtlılığı ve kullanım normu oluşabilir. (58)'de bozmak fiilinin olumsuz sözcük biçimi iyelik kategorisiyle ve durum ekiyle eşdizimlenmiştir. Bunun da çoğu zaman sözlükselleşmeye ve deyimleşmeye koşut olarak gerçekleştiği görülmekle birlikte farklı sözcük birleşmelerinde de söz konusu olabilir.

58) Ciddiyet-[i]-n-[i] bozma-dan, "Olabilir" dedi.

\section{Sonuç}

Sözlüksel unsurlar belirli dil bilgisel kategori ve biçimbirimlerle sıklık kullanımına bağlı olarak dilbilgiselleşmenin bir aşaması olarak kalıplaşmaya maruz kalır. Böylece belirli sözcük ve sözcük sınıfları belirli dil bilgisel kalıpları ortaya çıkarırken dil bilgisel kalıplar da belirli anlamları ortaya çıkarır. Sözcük ile dil bilgisi arasında etkileşimin gücünün ne denli olduğu derlem tabanlı eşdizimlilik araştırmalarıyla ancak ortaya konulabilir. Derlem tabanlı bu çalışmada sözcüklerin çeşitli alt tipleri olmakla birlikte yaygin ve belirgin 19 temel dil bilgisel eşdizimlilik kalıbının olduğu tespit edilmiştir. $\mathrm{Bu}$ kalıpların belirli anlam ve işlevleriyle belirli sözcükleri gerektirdiği belirlenmiştir. Türkçede sözcüklerin dil bilgisel eşdizimlilik örüntüsü, başka deyişle sözcüğün meydana getirdiği dil bilgisel yapılar 19 ile sınırlı değildir. Sözcüklerin hangi dil bilgisel yapılarda kullanıldığını ve hangi dil bilgisel yapıların ve kategorilerin hangi sözcük sınıflarını çektiğini belirlemek için geniş çaplı derlem çıkışlı araştırmaların yapılması gerekir. Sözcük kadar dil bilgisi olduğu düşünüldüğünde dil bilgisel kalıpların sayısı da o kadar fazladır. Ancak bu kalıplar belirli söz dizimsel ve anlamsal-işlevsel özelliklerine göre belirli kategorilere tabi tutularak sınıflandırılabilir. Dil bilgisel kalıplar biçimanlam çifti olarak bir gösterge gibi değerlendirilebilir, eş ya 
da yakın anlam ifade eden dil bilgisel kalıplar ve bu kalıplarda kullanılan sözlük unsurları anlam ve işlev temelinde tasnif edilebilir. Dilbilgiselleşme ve sözcüklerin sözlüksel özelliğini kaybedip yarı işlevsel ve yarı sözlüksel özellikler kazanması da dil bilgisel eşdizim araştırmalarıyla ortaya çıkarılabilir. $\mathrm{Bu}$ araştırmalar hem Türkçenin betimlenmesi ve dil bilgisi çalışmalarının derinlik kazanmasını sağlayacak hem de Türkçenin yabancı dil olarak öğretilmesinde kullanılabilecek önemli bilgiler sunacak. Zira dil öğrenmek yapı öğrenmekten başka bir şey değildir.

Tablo 2: Türkçe Dil Bilgisel Eşdizim Kalıpları

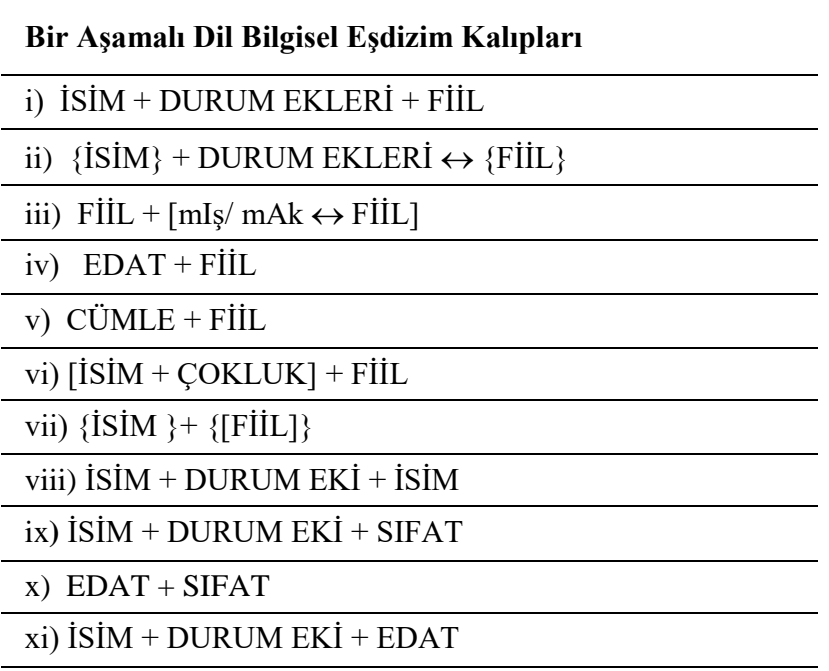

İki Aşamalı Dil Bilgisel Eşdizim Kalıpları

\begin{tabular}{l}
\hline i) FİIL + [-mA-] + DURUM EKİ + Fİ̈L \\
\hline ii) FİİL + [-mA-] + İYELİK + FİIL \\
\hline iii) $\{$ İSİM $\}+$ İYELİK + DURUM EKİ+ $\{$ FİIL $\}$ \\
\hline iv) $\{[$ İSİM + ÇOĞUL EKİ $]\}+$ DURUM EKİ + \{FİIL $\}$ \\
\hline v) $\{$ İSIM $\}+$ DURUM EKLERI + [Fİ̈L $]$ \\
\hline
\end{tabular}

\section{Üç Aşamalı Dil Bilgisel Eşdizim Kalıpları}

i) Fİ̈L + (-dIk/ -AcAk) + IYYELIKK + DURUM EKİ + Fİ̈L

ii) FİIL + [-mA] + IYYELİK + DURUM + Fİ̈L

iii) $\{$ İSIM $\}+$ IYYLLIK + DURUM + \{[FİIL $]\}$

\section{Kaynakça}

Aksan, Y., Aksan, M., Koltuksuz, A., Sezer, T., Mersinli, Ü., Demirhan, U. U., ...Yıldız, İ. (2012). Türkçe Ulusal Derlemi (TUD) Tanıtım Sürümü Sözcük Slklı̆̆ Listeleri Teknik Rapor-1. Mersin: Mersin Üniversitesi.

Benson, M., Evelyn Benson, Robert Ilson. F. (1997). The BBI combinatory dictionary of English. Amsterdam/Philadelphia: John Benjamins Publishing Company.

Boz, E. (2018). Sözlükler İçin Yeni Bir Dilbilgisel Bilgi Önerisi: İlgeçlerin Atadıkları Biçimbirimler. Uluslararası Türkçe Edebiyat Kültür Eğitim Dergisi, 7(2), 749-758.
Corver, N., van Riemsdijk, H. (2001). Semi-lexical categories : the function of content words and the content of function words. İçinde: N. Corver \& H. van Riemsdijk. Berlin, New York : Mouton de Gruyter.

Çalışkan, N. (2014). Yüksek Sıklıktaki Adlar: Zaman Sözcükbiçimi Üzerine Derlem Temelli Bir Inceleme (Eşdizimlilikler, Biçimbirim Dizileri, Dilbilgisel Örüntüler, Semantik Prozodi). Ankara: Pegem Akademi Yayınları.

Çalışkan, N. (2019). Yabancı Dil Sınıflarında Tümleç Yan Cümlelerinin Öğretimi: Eşdizimlilik ve Semantik Eğilimler Temelli Bir Yaklaşım. Uluslararası Türkçe Edebiyat Kültür Eğitim Dergisi, 8(3), 17091741.

Çalışkan, N. (2019). diye Sözcüğü Üzerine Derlem Temelli Bir Betimleme. Türkbilig, 38, 163-176.

Çalışkan, N. (2019). Yüklem Konumundaki Sıfatlar İle Fiilimsi Tamlayıcıları Arasındaki Eşdizimlilik Ilişkileri. Dil Araştırmaları, Bahar 2019/24: 75-88

CROFT, W. (1991). Syntactic Categories and Grammatical Relations: The Cognitive Organization of Information. Chicago: University of Chicago Press

Doğan, N. (2016). Türkiye Türkçesinde Fiillerin Eşdizimleri. Ankara: Kitapevi.

Doğan, N. (2014). Çok İşlevlilik Açısından Edatların Söz Dizimsel ve Anlam Bilimsel Yapısı. Dil Araştırmaları, Sayı 15, 105-119.

Doğan, N. (2018). Söz Dizimsel Açıdan Türkçe Fiil Sinıfları. Uluslararası Türkçe Edebiyat Kültür Eğitim Dergisi, 7(4), 2204-2225.

Doğan, N. (2019). Türkçede Dilbilgisel Eşdizimlik, $X$. Uluslararası Dünya Dili Türkçe Sempozyumu Bildirileri, Eskişehir: Eskişehir Üniv. Yay.

Firth, J. R. (1968). A synopsis of linguistic theory, 19301955. İçinde: J. R. 1952- 1959, F. R. Palmerb (Ed.), Selected papers of Firth (s. 168-205). Bloomington: Indiana University Press,

Firth, J. R. (1957). Modes of Meaning. Papers in Linguistics 1934-1951, Oxford: Oxford University Press, s. 190-228.

Goldberg, A. E. (1995). Constructions. A construction grammar approach to argument structure. Chicago: University of Chicago Press.

Goldberg, A. E. (1996). Construction Grammar. İçinde K. Brown \& J. Miller (Eds.), Concise encyclopedia of syntactic theories (s. 68-71). Oxford: Pergamon.

Gries, S.T., Stefanowitsch, A. (2004). Extending collostructional analysis: a corpus-based perspective on 'alternations'. International Journal of Corpus Linguistics, 9(1), 97-129.

Hoey, M. (1997). Implementing the lexical Approach: Putting Theory into Practice. UK: Heinle ELT.

Hoey, M.P. (2005). Lexical Priming. A new theory of words and language. London: Routledge. 
Hunston, S. \& Gill, F. (2000). Pattern Grammar. A CorpusDriven Approach to the Lexical Grammar of English. Amsterdam and Philadelphia: John Benjamins.

Navalainen, T. (2004). Tree Persfetive on Grammaticalization: Lexico-grammar, corpora, and historical linguistics. İçinde: H. Lindquist \& C. Mair (Ed.), Corpus Approaches to Grammaticalization in English. Amsterdham: John Benjamins Publishing.

Yüceol Özezen, M. (2009). De- Fiilinin Grameri. Adana: Karahan Kitapevi.

Özsoy, A. S. (2001). On Small clauses, other bare verbal complements and featurechecking. İçinde: Erguvanl1-Taylan, E. (ed.), The Verbs in Turkish (s. 213-237). Amsterdam: John Benjamins.
Römer, U. \& Schulze, R. (Eds.). (2009). Exploring the Lexis-Grammar Interface. Amsterdam: John Benjamins.

Römer, U. (2009). The inseparability of lexis and grammar Corpus linguistic perspectives. Annual Review of Cognitive Linguistics 7, Amsterdam: John Benjamins Publishing Company.

Sinclair, J. (1998). The lexical item. İçin E. Weigand (Ed.), Contrastive Lexical Semantics (1-24). Amsterdam: John Benjamins.

Sinclair, J. (1991). Corpus, Concordance, Collocation. Oxford: Oxford University Press.

Stubbs, M. (2001). Words and Phrases. Corpus Studies of Lexical Semantics. Oxford: Oxford University Press

Zidani-Eroğlu, L. (1997). Exceptionally case-marked DPs as matrix objects. Linguistic Inquiry 28, 219-230. 